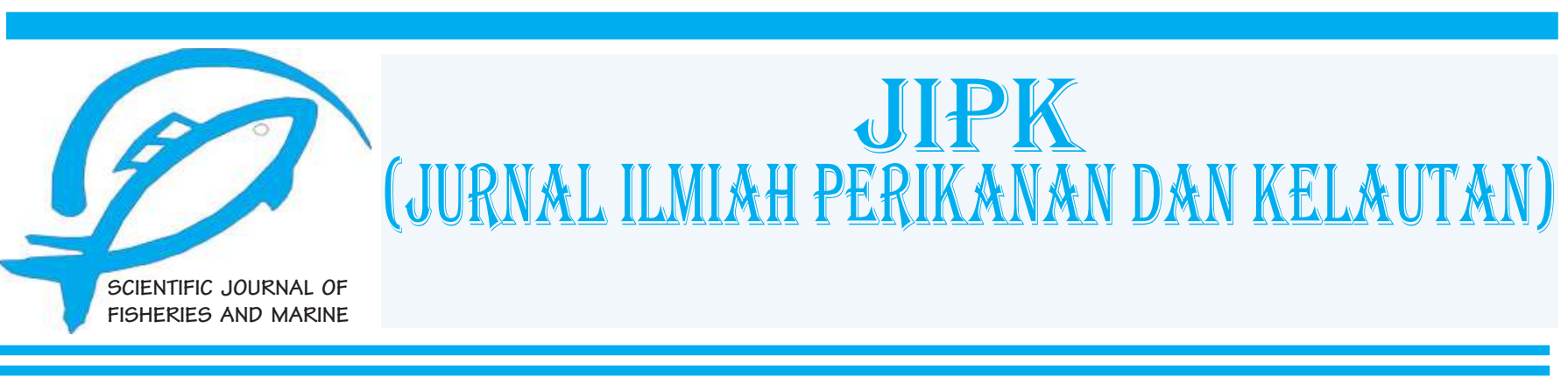

Research Article

\title{
Numerical Modeling of Tidal Current Patterns Using 3-Dimensional MOHID in Balikpapan Bay, Indonesia
}

\author{
Hadi Hermansyah $^{1}$ (D), Nining Sari Ningsih ${ }^{2}$, Nabil $^{3}$, Ayi Tarya ${ }^{2}$, Syahruddin $^{1}$ \\ ${ }^{1}$ Balikpapan State Polytechnic, Indonesia. \\ ${ }^{2}$ Oceanography Departement, Institut Teknologi Bandung, Indonesia. \\ ${ }^{3}$ Laboratory of Processing Data, IPB University, Indonesia
}

\section{OPEN \\ ACCESS}

\section{ARTICLE INFO}

Received: October 25, 2019

Accepted: Desember 22, 2019

Published: February 27, 2020

*) Corresponding author:

E-mail: hadi.hermansyah@poltekba. ac.id

\section{Keywords:}

numerical simulation

tidal current

MOHID hydrodynamics model

Balikpapan Bay

This is an open access article under the CC BY-NC-ND license (http://creativecommons.org/licenses/by-nc-nd/4.0/)

\begin{abstract}
Balikpapan Bay is significant as a link between the cities within and outside of East Kalimantan by becoming the primary path used for local transportation and distribution of produced goods. The various anthropogenic activities increased liquid wastes and debris, which flowed through channels and rivers along the bay. This study aimed to determine tidal current patterns in Balikpapan Bay and its influence on salinity and temperature distributions. This study applied a baroclinic three-dimensional (3D) hydrodynamic model, employing wind, tides, and density variations, resulting from the differences of temperature and salinity, as the model input. To simulate the tidal current flow, we applied MOHID Water Modeling System, which the tidal current patterns depicted current directions and speeds at the different tidal conditions. During the displacement toward the high tidal condition, the water mass moves northwestward entering the river body, while at the displacement toward the low tidal condition, the water mass moves southeastward, which flows toward the coast and without the bay. The current speed varies at certain tidal conditions. At the highest tidal condition, the surface elevation ranged $1.3-1.5 \mathrm{~m}$ above mean sea level; the current rate is lower compared to the displacement toward high tidal condition, which ranged from $0.01-0.15 \mathrm{~m} / \mathrm{s}$. At the lowest tidal condition, the surface elevation reached $1-1.2 \mathrm{~m}$ below mean sea level, and the weaker flow velocity took place (less than $0.15 \mathrm{~m} / \mathrm{s}$ ). The results also showed that the water mass temperature tends to be higher in the inner part of Balikpapan Bay, the Balikpapan Bay waters profile that is increasingly shallow towards the bay head also causes this area to tend to have a higher temperature. Also, areas located on the inside of the bay tend to get more freshwater input from rivers, so this area has lower salinity while the area located at the mouth of the bay tends to be of higher salinity because it gets a lot of mass input of seawater from the Makassar Strait.
\end{abstract}

Cite this as: Hermansyah, H., Ningsih, N. S., Nabil, Tarya, A., Syahruddin. (2020). Numerical Modeling of Tidal Current Patterns Using 3-Dimensional MOHID in Balikpapan Bay, Indonesia. Jurnal Ilmiah Perikanan dan Kelautan, 12(1):9-20. http://doi. org/10.20473/jipk.v12i1.16257 


\section{Introduction}

Balikpapan Bay is a bay located between Balikpapan City and Penajam Paser Utara Regency. The shipping lane in this bay is very congested because it is the entry and exit points of large vessels, both passenger ships as the primary means of transportation from Balikpapan to Penajam Regency, and fuel transport vessels for industrial purposes. Some development activities are developing rapidly in this bay, such as industry, mining, plantation, fishery, agriculture, and forestry (PPKT, 2004). According to BPS (2013), the number of large and medium-sized industrial companies in East Kalimantan as of 2013 was 115 companies consisting of agriculture, food and beverage, chemical, mining and textile sub-sectors. These various industrial activities have the potential to produce liquid waste and rubbish, which are generally carried along by the flow of rivers along the bay.

Balikpapan Bay is a semi-closed bay located in East Kalimantan. It directly faces the Makassar Strait, making it possible for physical processes to bring marine wastes and debris from the sea into the bay or vice versa. This influence is proven through the results of CTD observations by Wayan et al. (2016), which clearly showed the feature of salinity that changed drastically from outside the bay to the bay mouth, where salinity increased as it gets closer to the sea zone. Nur et al. (2018), through the ROMS numerical model, explained the role of regional processes in triggering the dynamics of water mass within the bay as well as the freshwater mass that affects the variation in inspatial and temporal salinity. Low salinity is distributed from tributaries that flow into the bay with a relatively high discharge throughout the year hence the mass flux of low-salinity water is always involved in influencing the water mass dynamics in Balikpapan Bay. In semi-closed bays, the tidal regime will dominate the transport mechanism where it oscillates the high-salinity water into a semiclosed bay.

Problems associated with sediment transport in the coastal areas are sedimentation, abrasion, and the increase of turbidity. Sedimentation and abrasion are related to tides and waves features. The vertical sediment transportation depends on many factors when the tide occurs, the material will settle down, while at low tide, the material will erode (Qomariyah \& Yuwono, 2016). Abrasion phenomena result in shoreline changes that can be triggered by the movement of sediment driven by wave-induced longshore current (Angkotasan et al., 2012; Supiyati et al., 2013; Oktiarini et al., 2015; Wisha et al., 2015). The area around the estuary is tremendously complex because the interaction of several interrelated processes take place. Thus, in the estuarine waters, the possibility of significant changes (on a scale of time and space) caused by longshore currents, waves, and tides is higher. The confluence between river streams (Wain, Riko, and Semoi Rivers) and tidal current flow affects the sediment transport features within Balikpapan Bay.

Balikpapan Bay is one of the bays directly connected to the Makassar Strait. That means the Makassar Strait influences the hydrological conditions at the bay. Periodically, the input of freshwater from the river moves into the bay area, and at the same time, seawater from the Makassar Strait enters the bay and increases the temperature and vertical structure of the air mass in the Balikpapan bay. The width of the bay channel varies significantly and has a range of $\sim 6 \mathrm{~km}$ at the bay mouth to $<1 \mathrm{~km}$ at the upstream side. With channel lengths of $>40 \mathrm{~km}$, many dynamic processes can occur along the bay channel, such as partial mixing, salt intrusion, and transportation of sediment from rivers (Nur et al., 2018).

Water mixing in the estuary has a vital role in forming ecological and hydrological characteristics (Hettiarachchi, 1997). The influence of tidal and tidal forces will cause a different seawater mass input according to the water conditions. The mass of seawater will flow into the estuary to a considerable distance during high tide, whereas when the ebb tide, the mass of bay water comes out again from the estuary to the sea (Triatmodjo, 1999). The flow of the river will carry and accumulate nutrients into the sea and spread it into a larger ocean system. The interaction between freshwater mass and seawater mass in the bay area can be explained by knowing the area of low salinity water mass flowing into the sea.

Some basic things have not been studied in Balikpapan Bay, including what causes some parts of the Gulf to be more contaminated than others? Also, what is the capacity of the bay to accommodate sources of pollution originating from watersheds and from the inside of the bay itself to achieve good water quality? (Schoellhamer, 2007). Knowledge of the basic physical processes of water masses that govern hydrological structures is very much needed for a better understanding of complex physical-biological interactions (Koutsikopoulos et al., 1999). In this paper, the dynamics of water mass in Balikpapan Bay will be explained. The purpose of this study is to understand the dynamics of water mass in Balikpapan Bay using MOHID-3D by analyzing temperature, salinity structure, and density as well as the current pattern. 
This study is also beneficial to local government in planning and controlling the environmental issues by determining the transport mechanism in Balikpapan Bay so that further developments in the future will be more environmentally friendly.

\section{Materials and Methods}

\subsection{Study Area}

This research was conducted in Balikpapan Bay with a longitude of $116.6-117 \mathrm{E}$, and latitude of $1-1.5 \mathrm{~S}$. Bathymetry in the study area (Figure 1) varies between 0 up to $50 \mathrm{~m}$. In the bay mouth, the water depth ranges from $10 \mathrm{~m}$ up to $50 \mathrm{~m}$ and within the bay ranges from 0 $\mathrm{m}$ up to $20 \mathrm{~m}$. There is a channel with a depth of more than $10 \mathrm{~m}$ in the middle of the bay that is connecting the bay mouth and within the bay. The channel formation is not only espousing the transportation activities but also increasing the discharge of seawater entering the Balikpapan bay. The red square (Figure 1) shows the location of the river discharge used as the model input, detailed in the field measurements section (red dots) (Figure 2). The time-series point is sampled at Semayang Port as the model validation point assessed with sealevel observation, and there are two-time series points in the bay mouth and the Balikpapan bay to quantify the surface currents formed as shown in Figure 2.

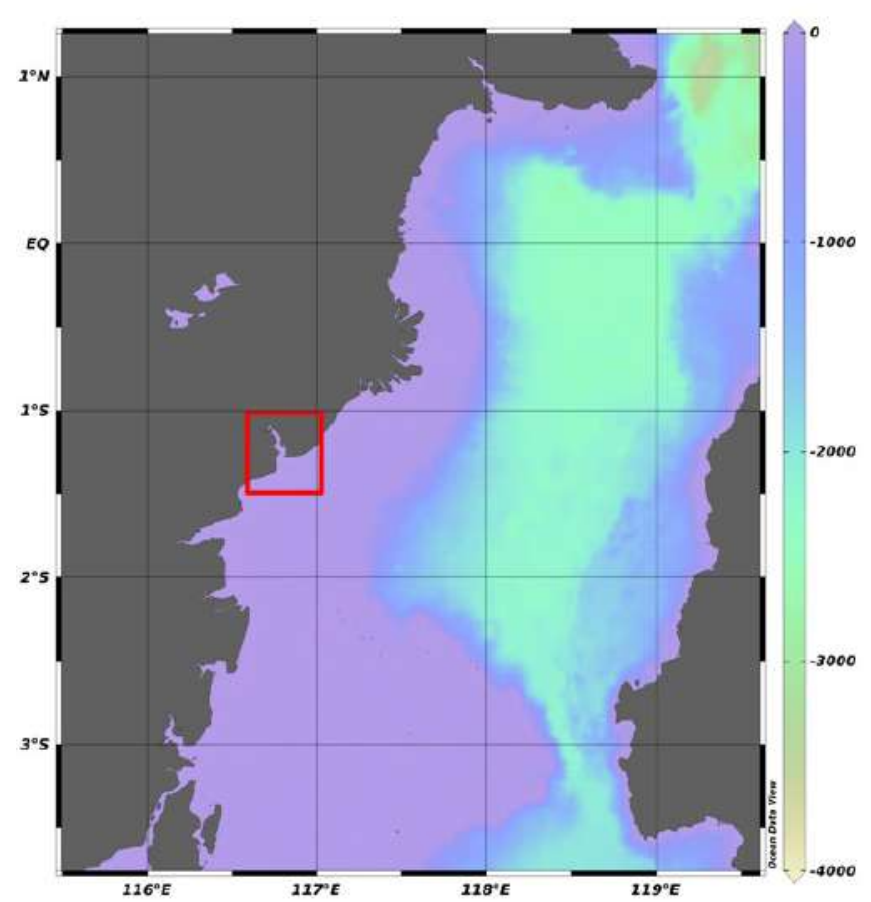

Figure 1. The map of study area (marked with a red square)

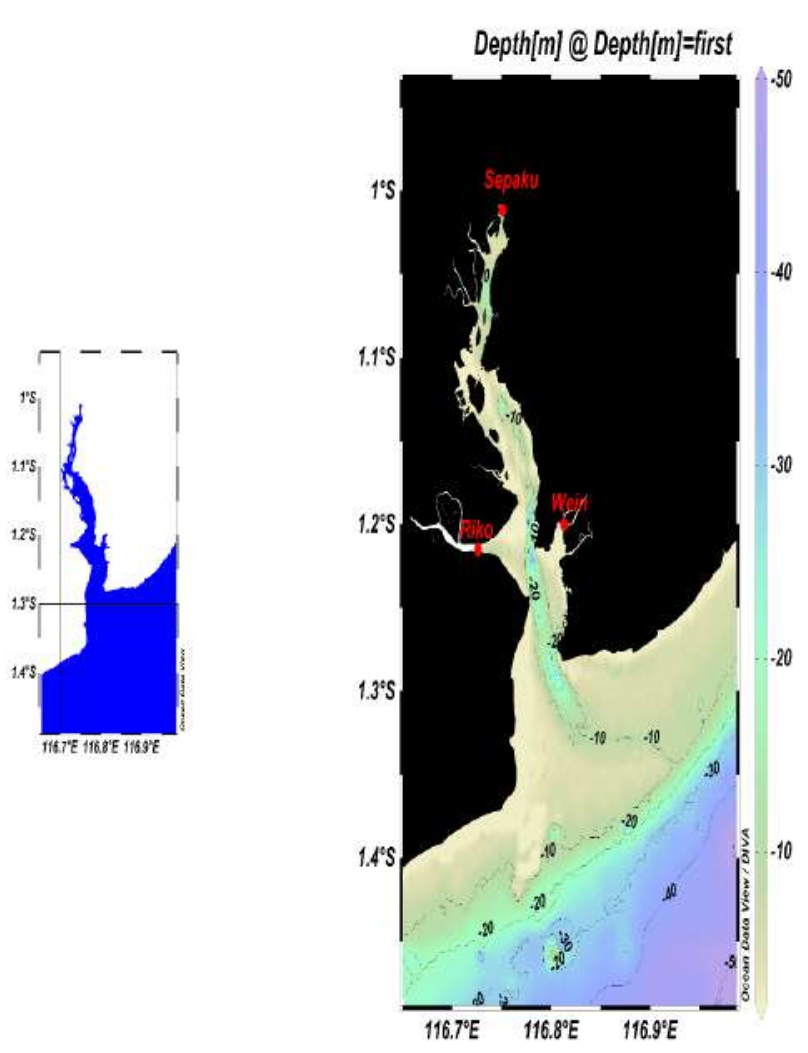

Figure 2. Bathymetry domain of Balikpapan Bay

\subsection{Field Measurement}

Field measurement data used in this study are the hourly sea level monitoring from Geospatial Information Agency (BIG) retrieved from http://tides. big.go.id/pasut/index.html during August 2019. These data are a direct measurement recorded by a tide gauge located at Semayang Harbor near the Balikpapan Bay mouth, which is used as the model validation to assess the error value of the simulated model at the same time and interval. The river discharge data are assumed implemented constantly implemented in the simulation, which was obtained from a field survey in 2002 conducted by the erosion and sedimentation working group in Balikpapan Bay. Three main river discharges were used in this study, including Riko River, Wein River, and Sepaku River (Figure 2).

\subsection{Data}

\subsubsection{Model Input}

The hydrodynamics model was simulated in Balikpapan Bay by which the model input consists of bathymetry, tidal, salinity temperature, and surface wind data. Bathymetry data were obtained from the Center for Hydrographic and Oceanography of the Indonesian 
Navy (Pushidrosal), which was then interpolated with a 1/100-degree grid resolution. Surface winds are retrieved from the NOAA Earth System Research Laboratory (ESRL) with a spatial resolution of 2.5 degrees and a period of 6 hours (web page: https://www.esrl.noaa. gov.html). Tidal data were obtained from the 2004 Finite Element Solution (FES) tidal model (Lyard et al., 2006), based on the hydrodynamic model assimilated by tidal devices and altimetric data (TOPEX/ Poseidon and ERS-2). The FES 2004 model was obtained from AVISO (web page: https://www.aviso.altimetry.fr) covering all global waters of each tidal component with a resolution of $1 / 8^{\circ}$.

\subsubsection{Hydrodynamics model}

The Hydrodynamics Model in Balikpapan Bay was simulated using a 3D MOHID water modeling system with three sigma layers, which are a hydrodynamic model based on the Navier-Stokes equation with a Boussinesq and hydrostatic approaches. MOHID 3D is formulated in a volume approach up to generic vertical discretization, which allows the simultaneous implementation of various types of vertical coordinates. Navier-Stokes equation with Boussinesq and hydrostaticapproaches is formulated as follow:
The MOHID Water model assumes hydrostatic equilibrium and Boussinesq approximation. To discretize the equations, it uses finite volumes, makes discrete equations that can be used for control volume (cell), adjusts the changes not to depend on cell geometry, the use of a generic vertical coordinate (Ruiz et al., 2002). According to Blazek (Blazek, 2015), the main advantage of the volume-limited method compared to the difference-limited method by which spatial discretization is done directly in physical space, which avoids problems related to the transformation between physical coordination and the coordinate equation system.

\subsection{Model Simulation}

Simulations are carried out from August $1^{\text {st }}$ $15^{\text {th }}, 2019$, representing the northeast monsoon, where the month represents the west season. The domain model consists of three open boundaries, namely the northern, western and southern open boundaries, and at each point of open boundary, the tidal elevation is predicted from Tidal Model Driver (TMD) (Padman and Erofeeva, 2005). The water mass movement model

$$
\begin{gathered}
\frac{\partial u}{\partial x}+\frac{\partial v}{\partial y}+\frac{\partial w}{\partial z}=0 \\
\frac{\partial u}{\partial t}+u \frac{\partial u}{\partial x}+v \frac{\partial u}{\partial y}+w \frac{\partial u}{\partial z}-f v \\
=\frac{1}{\rho_{0}} \frac{\partial p}{\partial x}+\frac{\partial}{\partial x}\left(v_{H} \frac{\partial u}{\partial x}\right)+\frac{\partial}{\partial y}\left(v_{H} \frac{\partial u}{\partial y}\right)+\frac{\partial}{\partial z}\left(v_{t} \frac{\partial u}{\partial z}\right) \\
\frac{\partial v}{\partial t}+u \frac{\partial v}{\partial x}+v \frac{\partial v}{\partial y}+w \frac{\partial v}{\partial z}+f u \\
=\frac{1}{\rho_{0}} \frac{\partial p}{\partial x}+\frac{\partial}{\partial x}\left(v_{H} \frac{\partial v}{\partial x}\right)+\frac{\partial}{\partial y}\left(v_{H} \frac{\partial v}{\partial y}\right)+\frac{\partial}{\partial z}\left(v_{t} \frac{\partial v}{\partial z}\right) \\
\frac{\partial p}{\partial z}=-\rho . g
\end{gathered}
$$

where:

$\boldsymbol{u}, \boldsymbol{v}, \boldsymbol{w}=$ Velocity at the $x, y$, and $z$-direction $(\mathrm{m} / \mathrm{s})$

$\boldsymbol{f}=$ Coriolis parameter $(\mathrm{rad} / \mathrm{s}), f=2 \Omega \sin \phi ;$ $\left(\Omega=7.27 \times 10-5 \mathrm{~s}^{-1}\right.$ and $\phi$ is latitude $)$

$\boldsymbol{v}_{\boldsymbol{H}}$ and $\boldsymbol{v}_{\boldsymbol{t}}=$ Turbulent viscosity coefficient in the horizontal and vertical directions $\left(\mathrm{m}^{2} / \mathrm{s}\right)$

$$
\begin{array}{ll}
\boldsymbol{p} & =\text { Pressure }(\mathrm{Pa}) . \\
\boldsymbol{\rho} & =\text { reference density }\left(\mathrm{kg} / \mathrm{m}^{3}\right), \rho=1024.78 \mathrm{kgm}^{3}
\end{array}
$$

is generated through tides obtained from the 2004 Finite Element Solution (FES) at the outer boundary of the model. Tidal components involved in this model include M2, S2, O1, K1, K2, N2, 2N2, Q1, P1, M4, Mf, Mm, Mtm, and Msqm with amplitudes and phases varying from the deep sea to shallow sea. At the surface boundary, the waters are driven by surface wind friction whose data is obtained from NCEP / NCAR with a temporal resolution of 6 hours during the simulation time. Horizontal discretization was used by utilizing a rectangular grid with a distance of $\sim 100 \mathrm{~m}$ from the 
bay mouth to the Bay of Balikpapan, with this distance, it is expected to be able to describe the variation of the flow entering the bay. Vertical discretization uses three layers of sigma layer with a depth division of $0.5,0.3$, and 0.2 and a maximum depth of $50 \mathrm{~m}$. Then, the initial conditions of temperature and salinity in Balikpapan bay waters are assumed to be constant with temperatures of $29^{\circ} \mathrm{C}$ and salinity of $30 \mathrm{PSU}$. Then input rivers are also considered in this model, including several rivers flowing into Balikpapan Bay, among others, Riko River, Wein River and Sepaku River (Semoi). The process of advection and diffusion is activated in this model to see the process of changing the river of low salinity into the bay system of higher salinity.

River (upstream) discharge is given by synthetic data of $1568.7 \mathrm{~m}^{3} / \mathrm{s}$, while wind data are given uniformly for all domain models (constant) but varies with time. The values of wind speed and direction during the simulation are shown in Figure 3. The bottom friction coefficient is determined by the Manning coefficient of $32 \mathrm{~m}^{1 / 3} / \mathrm{s}$ in which for the horizontal turbulence rate, the Smagorinsky coefficient is used with a constant value of 0.28 . While the distribution of wind frequencies in Balikpapan Bay is shown in Figure 4. Simulations were performed with some scenarios that are a scenario that considers tides and river discharges as current generators and a situation that considers the wind influence (tide + discharge + wind).

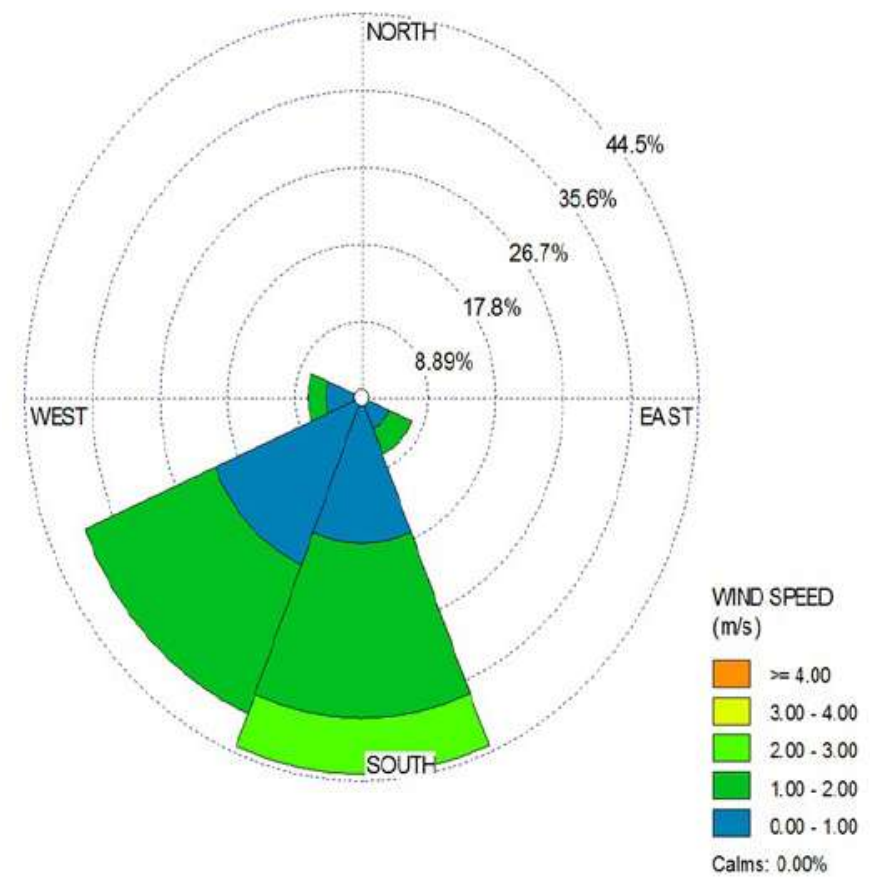

Figure 3. Wind rose during the simulation period

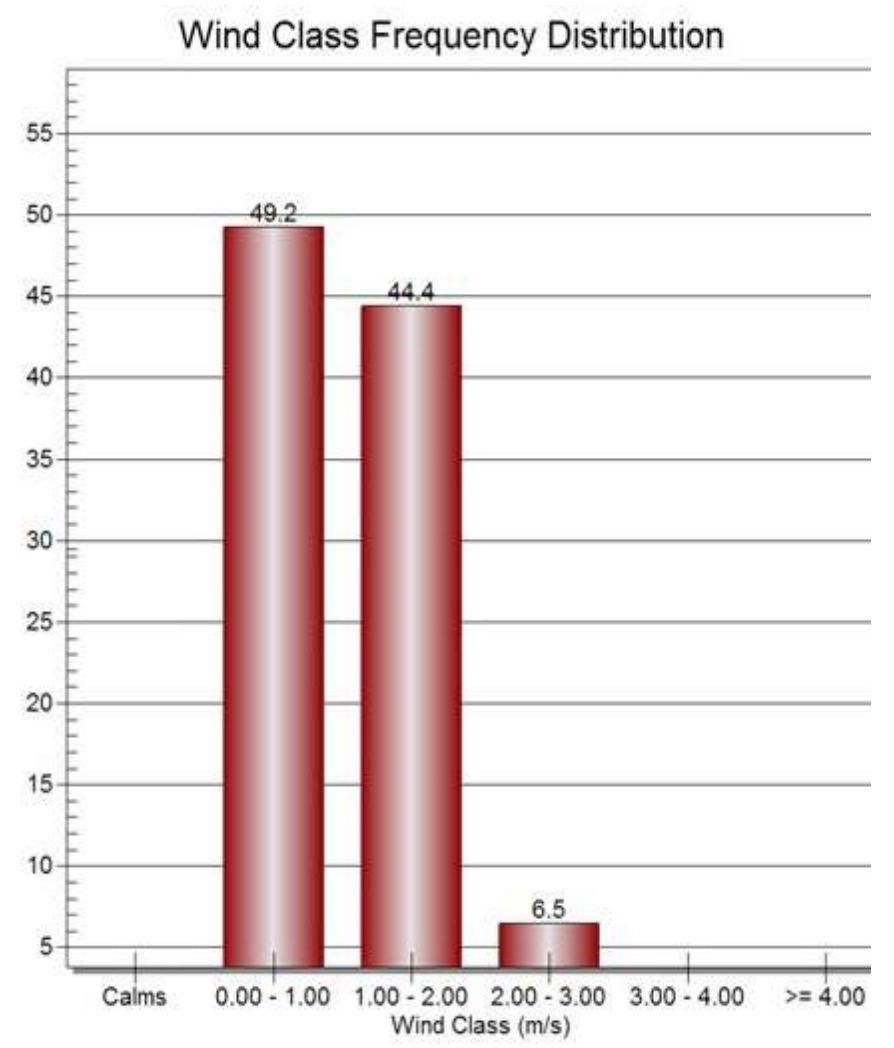

Figure 4. Distribution of wind frequencies in Balikpapan Bay

\section{Results and Discussion}

\subsection{Model Validation}

The comparison between model and observation data shows a similarity in amplitude and phase formed (Figure 5). Validation analysis applied to between surface elevation data resulted from the hydrodynamic model and BIG tidal observation results in a value of 0.975 out of 1 , which means that the hydrodynamic model has a good performance in representing the actual conditions in the field. The assessed time series are the first 15 days of August 2019 which shows the same phase of surface elevation, while on the day $11^{\text {th }}$ until the end of simulation, those two curves are slightly stretched and erratic which the amplitude difference is about $5 \mathrm{~cm}-15 \mathrm{~cm}$. Altogether, these results of validation highlight the capacity of the MOHID Water Model to simulate very dynamic tidal propagation in the bay. Tidal wave strengthened when it moves into the coast as a consequence of the reduction of the depth which, along with rising velocity flow, this causes the refraction of the tidal wave and consequently, the increase of its amplitude. 


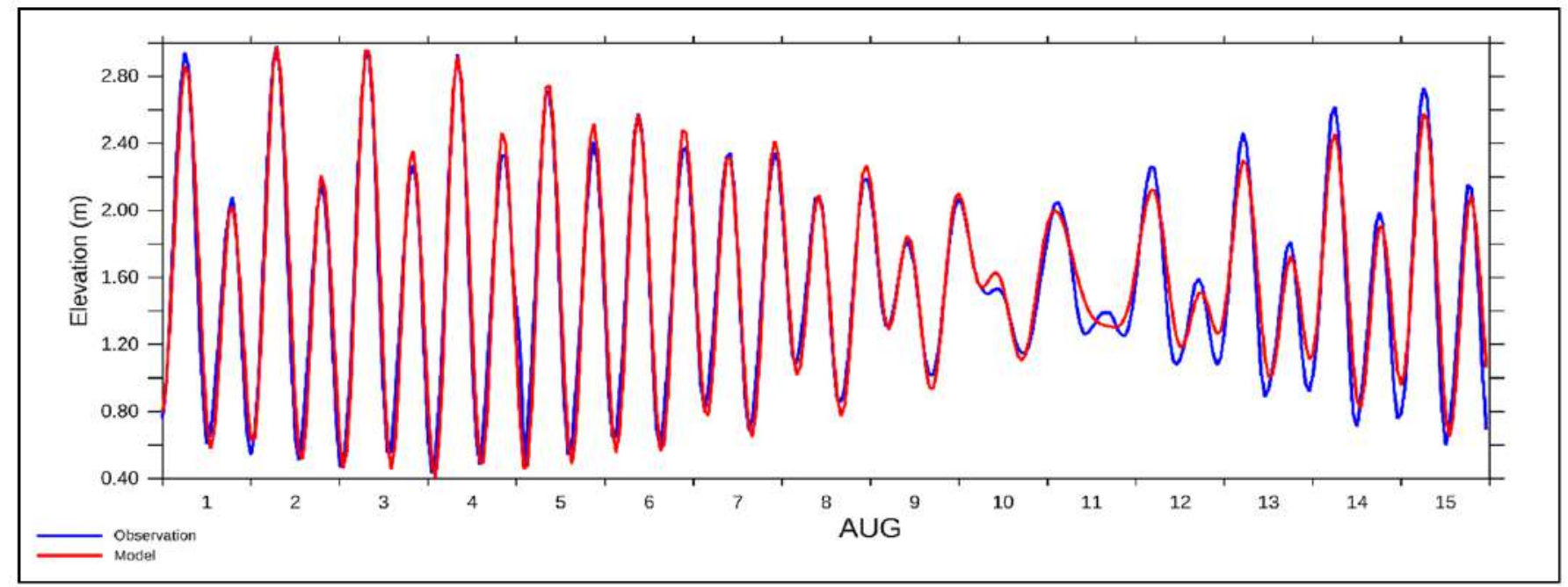

Figure 5. Model validation using surface elevation data resulted from model (red) and field measurement (blue)

\subsection{Tidal current patterns based on the model developed}

The variation in sea level at the high tidal condition has quite high changes, which can be seen from the tidal current propagation from open boundary to the bay area (Figure 6). At the flood tide condition, the tidal current reaches its maximum speed of magnitude about 0.8 $\mathrm{m} / \mathrm{s}$ and mostly flowing from the northeast direction (Makassar strait) toward Balikpapan Bay coastal waters. At high tide condition, the water level is positioned between $1.3-1.5 \mathrm{~m}$ above mean sea level, but the current speed decreases to $0.01-0.15 \mathrm{~m} / \mathrm{s}$ and changed direction from southwest to northeast and toward Balikpapan Bay. These conditions indicate a clear physical motion mechanism, where tides are the driving force for highsalinity water masses from the Makassar Strait towards the bay. The results of the model also show that there is a difference in the direction of the current when in the flood condition, where the tidal current in the mouth of the bay flows from the northeast direction (Makassar strait) towards the bay, while the tidal current from the head of the bay toward into the bay. These conditions occur because of the role of the Sepaku River, which pushes the mass of freshwater into the bay and the formation of different tidal propagation phases between the mouth and the body of the bay (Figure 6a).

At the displacement toward the high tidal conditions, the water mass movement speed had decreased while moving predominantly northwestward. In the eastern part of the study area, precisely from the bay mouth until Riko River, the water level is around 0.72 to $0.0 .75 \mathrm{~m}$. Within the river area, the water level elevation decreased around 0.65 to $0.7 \mathrm{~m}$. This elevation difference causes the current to tend to move northwestward entering the river. The simulation results also showed that the current pattern moves from the southeast toward northwest in which the maximum current magnitude is observed in the southeast(mouth of the bay) ranged $0.65-0.80 \mathrm{~m} / \mathrm{s}$. The current magnitude becomes weaker around Riko and Semoi River or Sepaku area (Figure 6a). At a depth of 15 meters, the current circulation moves northwest with the maximum speed that was observed in the southeast part of Balikpapan Bay and starts to decrease in the estuaries of the Riko and Wain Rivers (Figure 7).

At the highest water level, the current profile is relatively calm with very low speed, moving northwestward, the surface elevation is above $1 \mathrm{~m}$ over the model area (Figure 6b). It is calm because it in the slack water phase where there is no energy-induced current for a moment. The water level increased in the northwest part with elevation values around $1.3 \mathrm{~m}$ and $1.5 \mathrm{~m}$ (Figure 6b). The current pattern at a depth of 15 meters is relatively similar to the surface pattern. The current moves northwestward with a slightly slower speed in the coastline (Figure 8).

During the low tidal conditions, the water level varies between $1 \mathrm{~m}$ to $1.2 \mathrm{~m}$ beneath the mean sea level with lower flow velocity (less than $0.15 \mathrm{~m} / \mathrm{s}$ ). The variation of water level within the bay is lower than the water level at the open seas and the bay mouth, this difference also occurs in other conditions. At the displacement toward the lowest ebb tides, the current speed reaches its peak $(\sim 0.8 \mathrm{~m} / \mathrm{s})$. The reversed direction of the current was also seen between the bay mouth and within the bay, wherein the bay mouth, the surface currents move toward the open sea and vice versa.

Current circulation patterns generated by tides, winds, and rivers discharges are moving southeastward with the expanded velocity toward the southeast. The surface elevation ranges from -0.7 up to $-0.6 \mathrm{~m}$ 

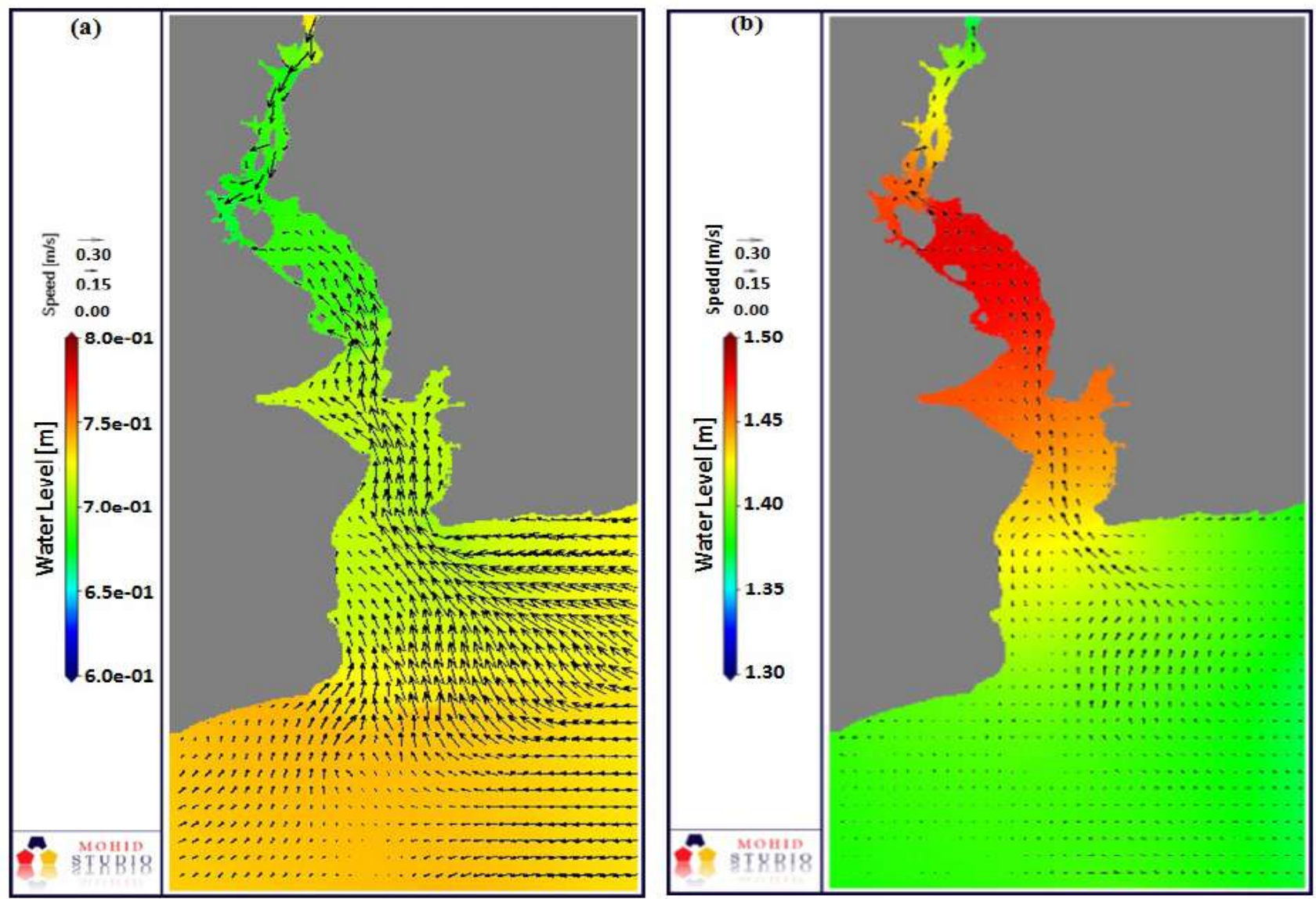

Figure 6. Tidal current patterns during the displacement toward the high tidal conditions (flood) (a) and during the highest elevation of tides (b)

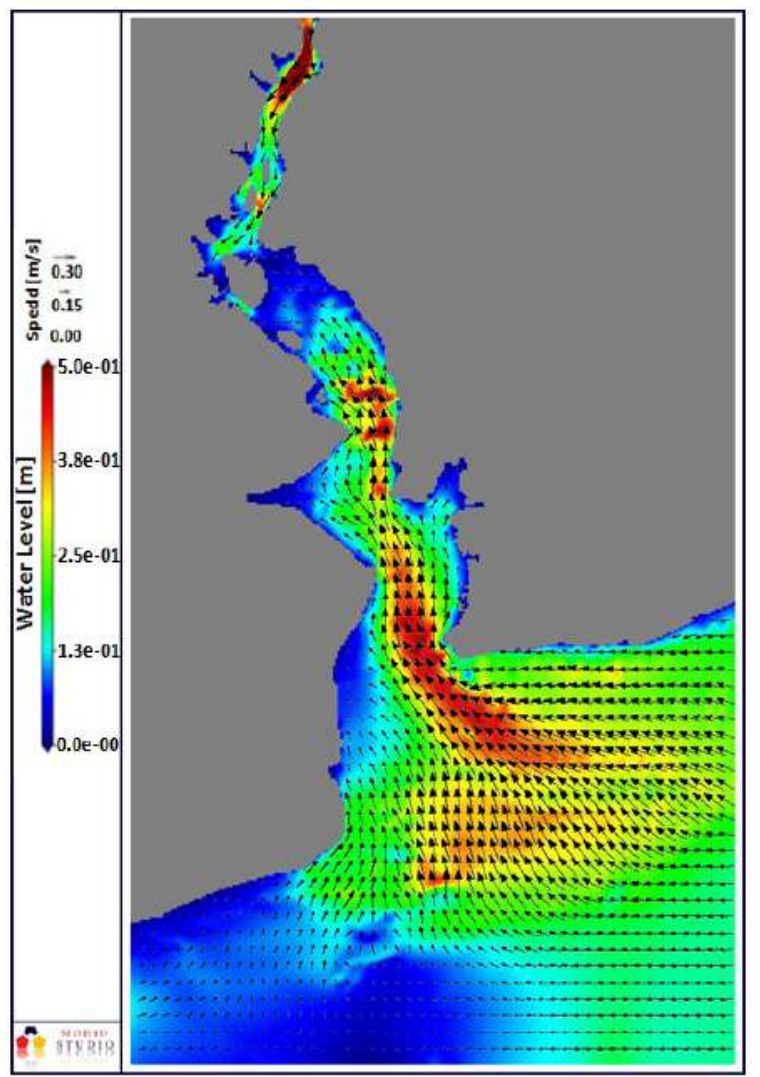

Figure 7. Tidal current pattern at the displacement toward the high tidal conditions at the depth of $15 \mathrm{~m}$.

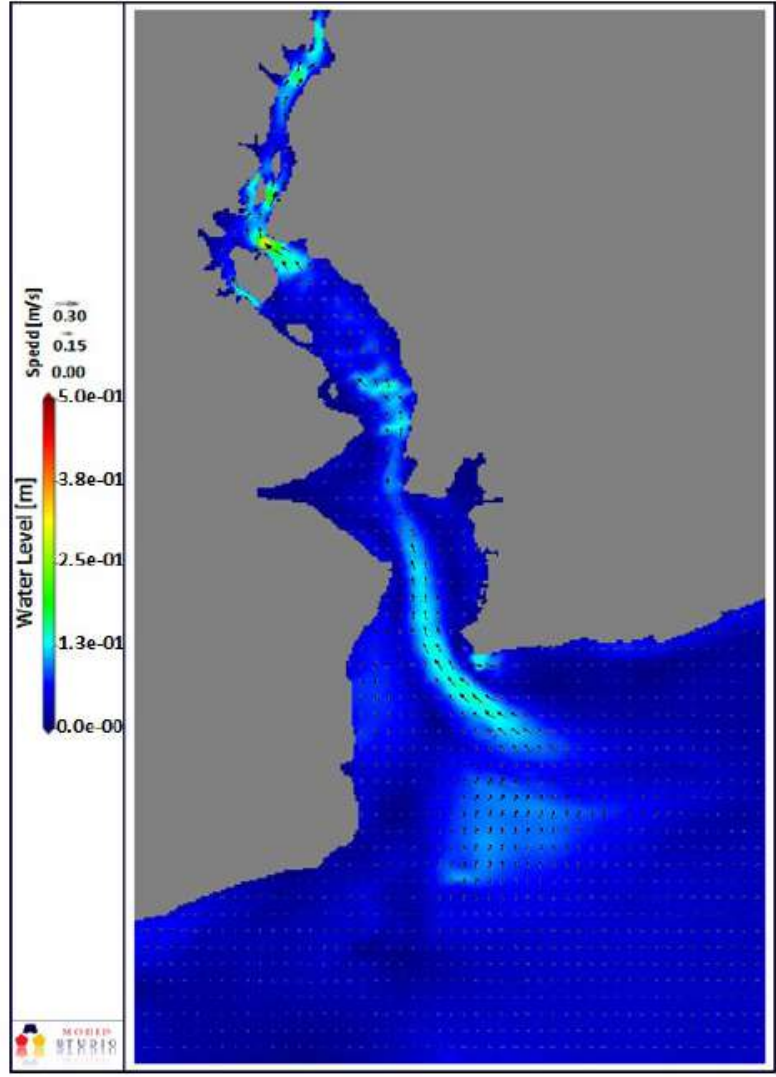

Figure 8. Tidal current pattern at the highest tidal condition at the depth of $15 \mathrm{~m}$ 
in the southeast, while in the northwest, the surface elevationis relatively higher ranging from -0.5 up to -0.65 $\mathrm{m}$. This elevation difference causes the current to reverse southeastward. The simulation results show that the current is moving southeastward with the velocity magnitude distributed uniformly throughout the model area (Figure 9a).

At the lowest ebb tides, the water level is ranged from -1.15 up to $-1 \mathrm{~m}$. The current moved southeastward with the maximum current speed observed in the southeast (Figure 9b). While at a depth of 15 meters, the current pattern is moving southeastward with the maximum velocity observed in the southeast (Figure 11).
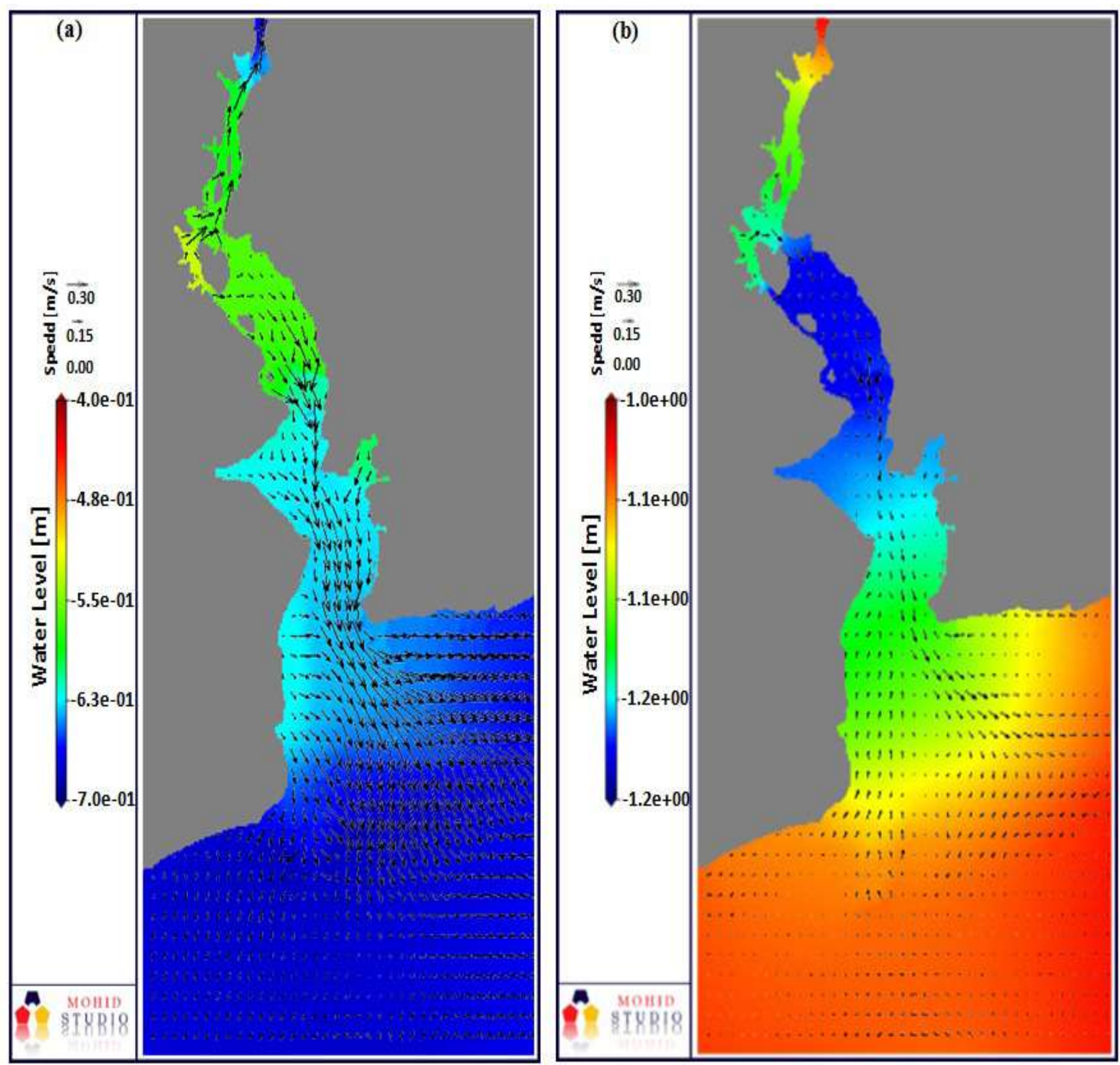

Figure 9. Surface current patterns during the displacement toward the low tidal conditions (ebb) (a) and during the lowest elevation of tides (b)

Current circulation patterns generated by tides, winds, and river discharges move toward the southeast with tremendously low speed (close to zero). The water level gradually decreased toward the northwest, where the elevation in the north is around -1.25 up to -1.1 meters and in the northwest ranges from -1.2 to $-1.25 \mathrm{~m}$ (Figure 9b).

The current pattern at displacement toward the low tidal condition at a depth of 15 meters is moving northward with the maximum velocity observed in the southeast part or the bay mouth (Figure 10). In the river body at a depth of 15 meters, the current moves downstream with a speed of $0.2 \mathrm{~m} / \mathrm{s}$ out of $0.5 \mathrm{~m} / \mathrm{s}$ (Figure 10). The velocity of tidal currents is higher on the surface and gradually decreases bottomward. 


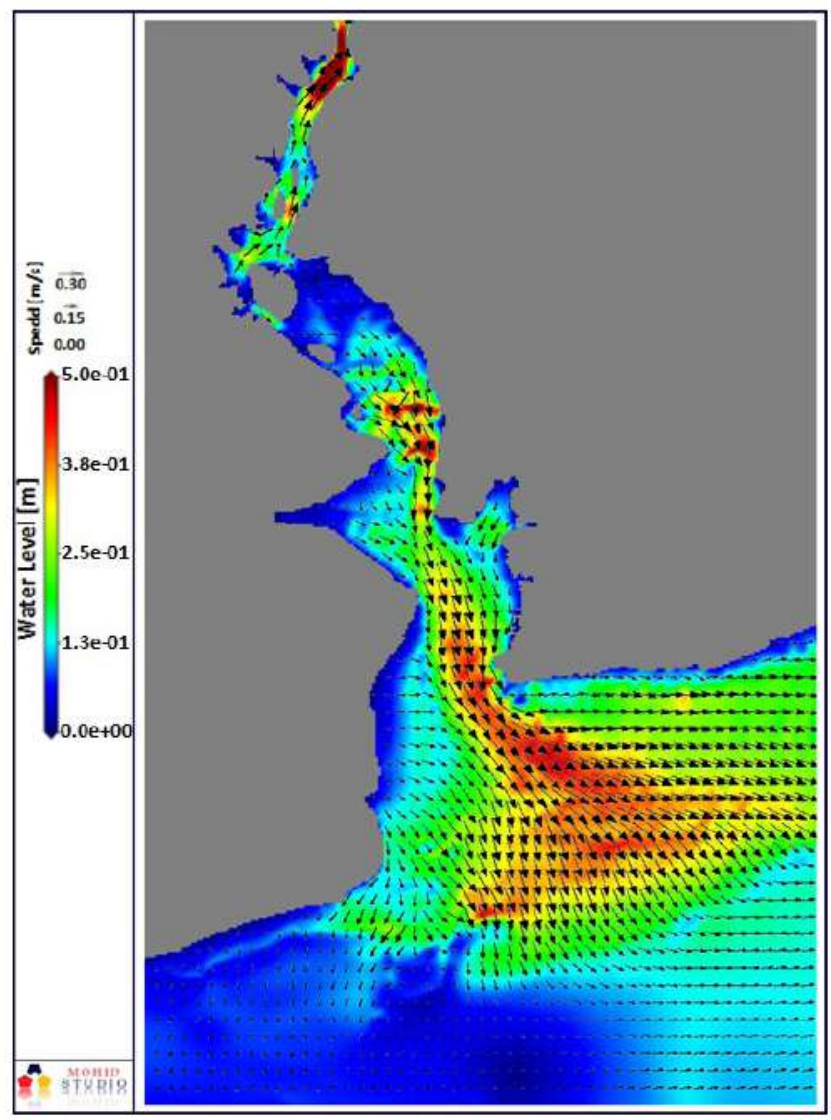

Figure 10. Tidal current pattern at the displacement toward the low tidal condition at the depth of $15 \mathrm{~m}$

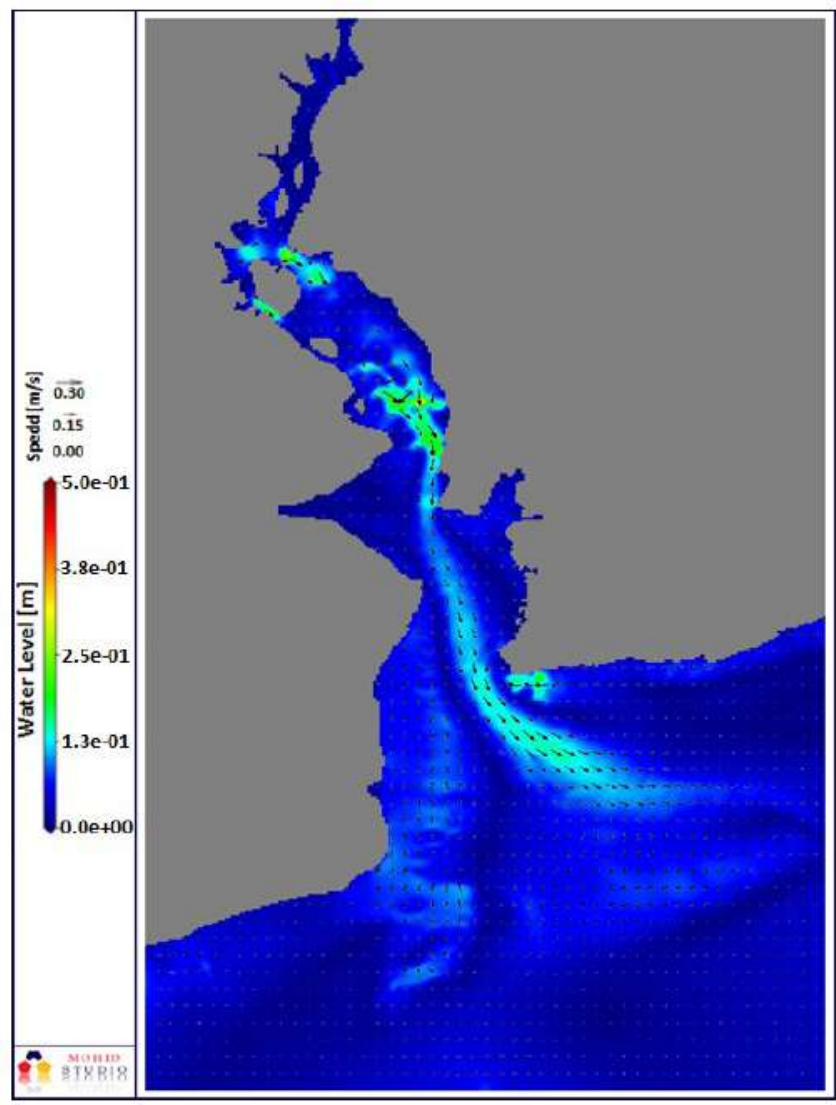

Figure 11. Tidal current pattern during the lowest televation of tides at the depth of $15 \mathrm{~m}$

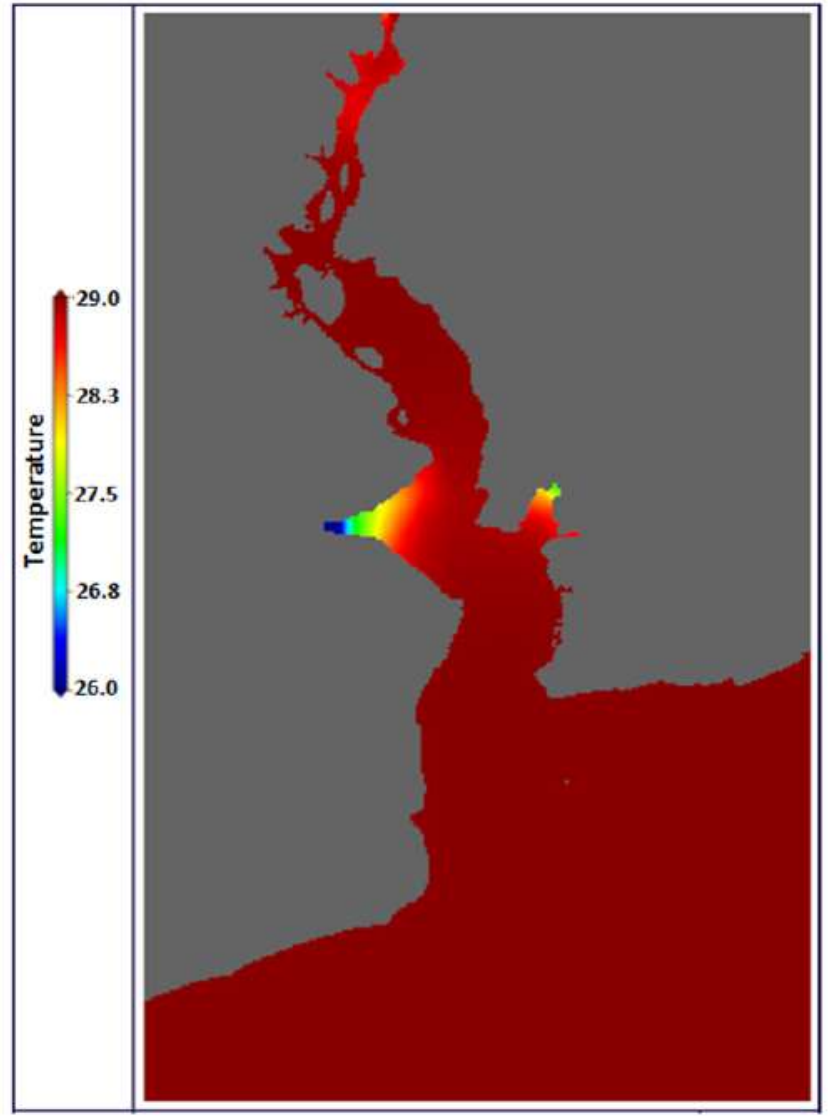

Figure 13. Temperature distribution in Balikpapan Bay

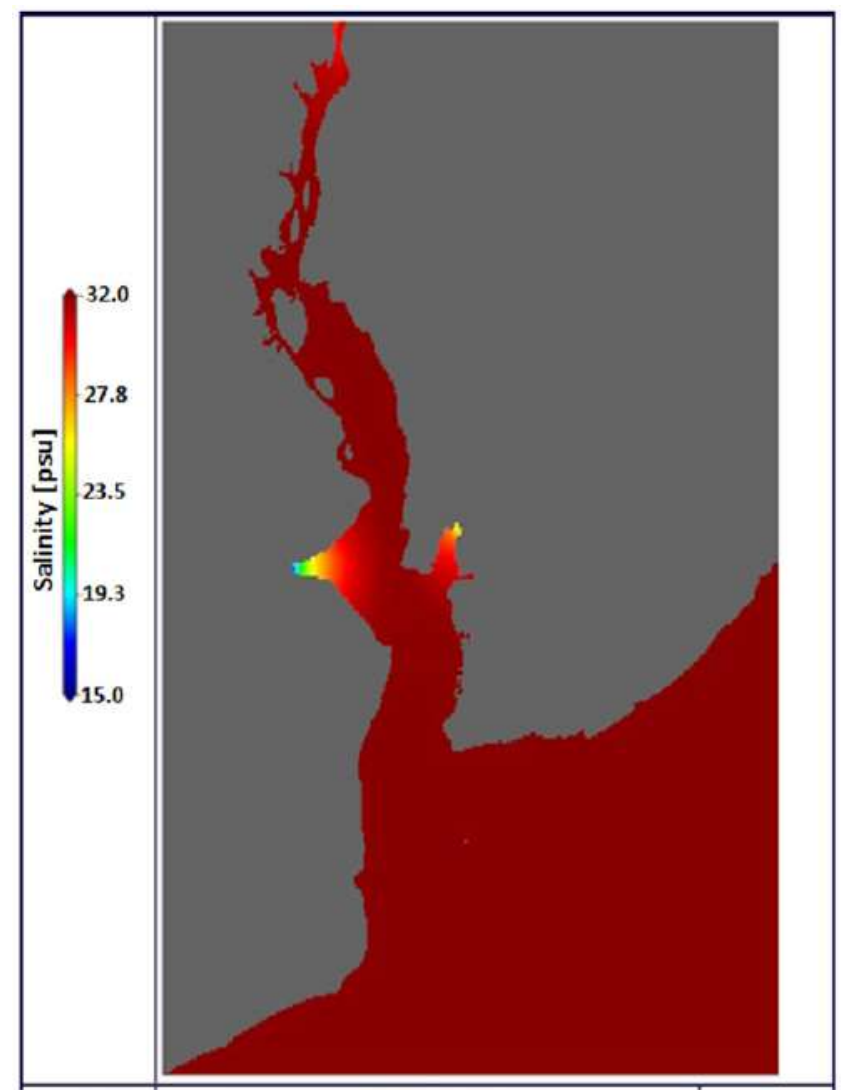

Figure 14. Salinity distribution in Balikpapan Bay 

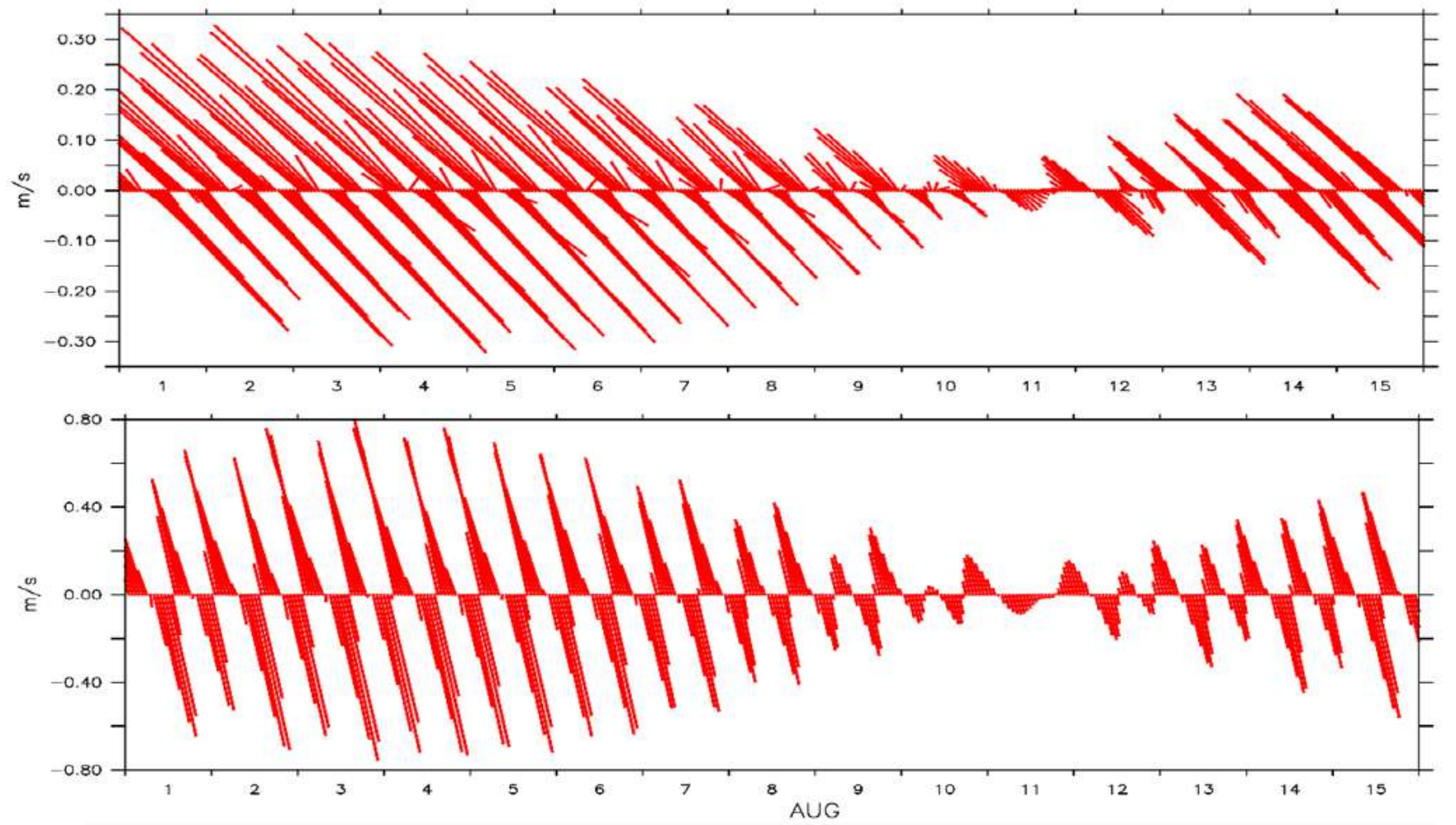

Figure 12. Sea current profile in the bay mouth (top) and within the bay (bottom)

\subsection{Sea current profile within Balikpapan Bay}

The time series of surface currents at two different points (in the bay mouth and within the bay) are depicted in Figure 12, which illustrates the variation of current speed and direction for 15 days (from the $1^{\text {st }}$ until $15^{\text {th }}$ August 2019). Current profiles at those two observation points have the same pattern, which follows the variation of tidal fluctuation formed from the open seas into the bay. The direction of currents between those two points is caused by the differences in morphology of the coast and bathymetry profile as well. As in the bay mouth, the current moves northwestward and southeastward, while within the bay, the currents tends to move to the north and south. The current speed within the bay is twice as fast as in the bay mouth.

\subsection{Spatial distribution of temperature and salinity}

The distribution of temperature during high tidal conditions ranged from $29.25-30.30^{\circ} \mathrm{C}$, where the highest temperature was observed within the bay, and the lowest temperature was observed close to the Riko River (Figure 13). The low temperatures flow from the bay mouth toward Riko River estuary. The temperature profile in the Sepaku tends to be higher, ranging from $30.15-30.30^{\circ} \mathrm{C}$. The relatively high temperature is also found in the peninsula area. According to Ross (1970), the heat transport in areas close to the equator tends to be higher because it receives more solar radiation than the other surrounding areas.
The distribution of salinity during the high tidal condition ranged from 27.75-30.00 PSU where the highest salinity was observed in the bay mouth area, and the lowest salinity was found within the bay close to Sepaku (Figure 14). In the Riko River estuary, low salinity was identified at approximately $27.75,28.00$, and 28.25 PSU. While the area in the bay mouth, the salinity profile ranged from 29.00-30.00 PSU. Water masses with low salinity ranging from 26.25-28.00 PSU were observed at a depth of $0-20 \mathrm{~m}$. The area within the bay is shallow $(<4 \mathrm{~m})$, therefore the mass of water in the area tends to accumulate and get a little input from seawater. Areas within the bay tend to get more freshwater input from the rivers along the bay than from the bay mouth area, and so this area has lower salinity. Seawater influence in the bay mouth sourced from Makassar Strait increases the mixing of salinity. According to Edmiston (2008), freshwater from rivers tends to have low salinity, so areas that get a lot of freshwater input from rivers will tend to have low salinity. This causes the waters column in Balikpapan Bay to experience mixed stratification of salinity.

\section{Conclusion}

The current patterns reversed in direction and changed in velocity on each tidal conditions. During the displacement toward the high tidal conditions, the southeast water mass moved northwestward, entering the river body and vice versa during ebb tides events 
(from the northwest to the southeast). The water flows from the river downstream near the coast. At the highest elevation of tides, the current velocity is lower than during the displacement toward flood tides. This condition indicates that the physical motion mechanism takes place, where the tides have a role in evoking the high-salinity mixing from Makassar Strait into the bay. The current profile in the bay mouth moves northward, and within the bay move southward. Semoi River has a role in pushing the freshwater discharge $d$ into the bay. On the other hand, the formation of different tidal propagation phases between the bay mouth and within bay also causes the oscillation transporting salinity dan temperature. The temperature profile in the peninsula region is higher because this area is located in lower latitudes hence it gets more solar radiation than the high latitude regions. The shallow condition within the bay also causes this area to be polluted by high temperatures. Water mass in Balikpapan Bay varies, surface salinity ranges from $31.00-34.25 \mathrm{psu}$.

\section{Acknowledgements}

Gratitudes are given to Mr. Ramli and Mr. Saiful Ghozi for their support of all research activities and facilities during a field survey in Balikpapan for many years.

\section{Authors' Contributions}

All authors have discussed the results and contributed from the start to the final manuscript; $\mathrm{HH}$ : responsible for the overall data collection and writing the initial until final draft of this paper. NAB: responsible for some data collection, particularly secondary data, and finding discussions. NSN, AT, SYAH: besides being involved in a few field works, they are also involved in the discussion of this paper.

\section{Conflict of Interest} interests.

The authors declare that they have no competing

\section{Funding Information}

This research was partially funded by the General Directorate of Research and Development, Ministry of Research, Technology \& Higher Education during 20192020 with grant number of 134/SP2H/LT/DRPM/2019.

\section{References}

Angkotasan, A. M., Nurjaya, I. W., \& Natih, N. M. (2012). Analisis Perubahan Garis Pantai Di Pantai Barat Daya Pulau Ternate, Provinsi Maluku Utara. Jurnal Teknologi Perikanan dan Kelautan, 3(2): 11-22.

[BPS] Badan Pusat Statistik. (2013). Statistik Industri
Besar dan Sedang Provinsi Kalimantan Timur Tahun 2013. Samarinda (ID): Badan Pusat Statistik Provinsi Kalimantan Timur.

Blazek, J. (2015). Principles of Solution of the Governing Equations. In Computational Fluid Dynamics: Principles and Applications, 3rd ed.; Blazek, J., Ed.; Elsevier Science: San Diego, CA, USA. pp. 121-166.

Deus, R., Brito, D., Kenov, I. A., Lima, M., Costa, V., Medeiros, A., Neves, R., \& Alves, C. N. (2013). Three-dimensional model for analysis of spatial and temporal patterns of phytoplankton in Tucuruí reservoir, Pará, Brazil. Ecological Modelling, 253: 28-43. http:// dx.doi.org/10.1016/j.ecolmodel.2012.10.013.

Edmiston, H. L. (2008). A River Meets the Bay: A Characterization of the Apalachicola River and Bay System. Florida (US): Apalachicola National Estuarine Research Reserve, Florida Department of Environmental Protection.

Hettiarachchi, S. S. L. (1997). Drainage and exclusion of salt-water in low-lying coastal areas. Ocean \& Coastal Management, 34(1): 29-53. doi: 10.1016/S0964-5691(96)00060-9.

Hutabarat, \& Evans. (1984). Pengantar Oseanografi. Jakarta: UI Press

[KKES] Kelompok Kerja Erosi dan Sedimentasi. (2002). Kajian Erosi dan Sedimentasi di DAS Teluk Balikpapan Kalimantan Timur. Technical Report Proyek Pesisir, TE-02/13-I, CRC/URI, Jakarta.

Koutsikopoulos, C., \& Cann, B.L. (1999). Physical processes and hydrological structures realted to the Bay of Biscay. Scientia Marina, 60: 9-19

Lopes, J. F., Dias, J. M., Cardoso, A. C., \& Silva, C. I. V. (2005). The water quality of the RiadeAveiro lagoon, Portugal: from the observations to the implementation of a numerical model. Marine Environmental Research, 60: 594-628. doi. org/10.1016/j.marenvres.2005.05.001

Lyard, F., Lefévre, F., Letellier, T., \& Francis, O. (2006). Modelling the Global Ocean Tides: A Modern Insight from FES2004. Ocean Dynamics, 56: 394-415.

Malhadas, M. S., Leitão, P. C., Silva, A., \& Neves, R. (2009). Effect of coastal waves on sealevel in Óbidos Lagoon, Portugal. Continental Shelf Research, 29:1240-1250. doi.org/10.1016/j.csr. 2009.02.007

Martins, F. A. (1999). Modelaçãomatemática tridimensional de escoamentoscosteiros e / estuarinosusandoumaabordagem de coordenada vertical genérica. $\mathrm{PhD}$ thesis. Portugal: Technical University of Lisbon.

Miranda, R. (1997). Nitrogen biogeochemical cycle 
modeling in the North Atlantic Ocean. MSc dissertation thesis. Portugal: Technical University of Lisbon.

Nontji. (1987). Laut Nusantara. Jakarta: Djambatan.

Nur, A. A., Mandang, I., Mubarrok, S., \& Riza, M. (2018). The changes of water mass characteristics using 3-dimensional Regional Ocean Modeling System (ROMS) in Balikpapan bay, Indonesia. IOP Conf. Series: Earth and Environmental Science, 162: 012006

Nurjaya, I. W., Surbakti, H., Hartanto, M. T., Gaol, J. L., \& Sulardi, A. (2019). Water mass dynamics in Balikpapan Bay, Eastern Kalimantan Indonesia. IOP Conf. Series: Earth and Environmental Science, 176 (2018) 012019

Oktariani, D., Atmodjo, W., \& Widada, S. (2015). Transport Sedimen di Lokasi Perencanaan Pembangunan Pelabuhan Marunda, Jakarta Utara. Jurnal Oseanografi, 4(1): 325-332.

Padman, L., \& Erofeeva, S. (2005). Tide Model Driver (TMD) Manual, Earth \& Space Research, Washington

[PPKT] Pemerintah Provinsi Kalimantan Timur. 2004. Rencana Strategis Pengelolaan Terpadu Teluk Balikpapan. Balikpapan (ID): Pemerintah Provinsi Kalimantan Timur.

Qomariyah, L., \& Yuwono. (2016). Analisa Hubungan antara Pasang Surut Air Laut dengan Sedimentasi yang Terbentuk. Jurnal Teknik ITS, 5(1): 1.
Ross, D. A. (1970). Introduction to Oceanography. New York (US): Appleton Century Croft, Meredith Corporation.

Ruiz-Villarreal, M. (2002). Hydrodynamic Model Study of the Ria de Pontevedra Under Estuarine Conditions. Estuaria Coastal Shelf Science, 54: 101-113.

Santos, A. J. (1995. Modelo Hidrodinâmico Tridimensional de Circulação Oceânica e Estuarina. Ph.D, Thesis, Universidade Técnica de Lisboa: Instituto Superior Técnico.

Schoellhamer, D. H., Mumley, T. E., and Leatherbarrow, J.E. (2007). Suspended sediment and sedimentassociated contaminants in San Fransisco Bay. Envirenmental Research, 105: 119-131

Supiyati, Suwarsono, \& Setiawan, I. (2013). Pola Transport Sedimen Akibat Arus yang Dibangkitkan Gelombang Di Pelabuhan Pulau Baai Bengkulu. Prosiding Semirata, 91-97. Bandar Lampung: FMIPA Universitas Lampung. Trancoso, A. R., Saraiva, S., Fernandes, L., Pina, P., Leitão, P., \& Neves, R. (2005). Modelling macroalgae using a 3D hydrodynamic-ecological model in a shallow, temperate estuary. Ecological Modelling, 187:232-246. doi.org/10.1016/j. ecolmodel.2005.01.054.

Triatmodjo, B. (1999). Tehnik Pantai. Yogyakarta (ID): Beta Offset.

Triatmodjo, B. (2011). Perencanaan Bangunan Pantai. Cetakan Pertama. Yogyakarta: Beta Offset.

Wisha, U. J., Husrin, S., \& Prihantono, J. (2015). Hidrodinamika Perairan Teluk Banten Pada Musim Peralihan (Agustus-September). Ilmu Kelautan, 20(2): 105. 